\title{
PENENTUAN LAPISAN TERKONTAMINASI RESIDU PUPUK MENGGUNAKAN METODA KELISTRIKAN PADA LAHAN PERTANIAN CEPAT PANEN
}

\author{
Ladaya A. Rakhmawati ${ }^{1, \text { a) }}$, Eleonora Agustine ${ }^{1, b)}$, Dini Fitriani ${ }^{1}$, \\ Mia Uswatun Hasanah ${ }^{1}$ \\ ${ }^{1}$ Universitas Padjadjaran, Jl. Raya Bandung - Sumedang Km. 21, Jatinangor, Sumedang, 45363 \\ Program Studi Geofisika, Fakultas Matematika dan Ilmu Pengetahuan Alam

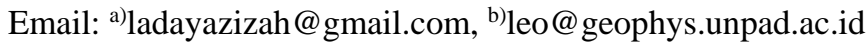

\begin{abstract}
Abstrak
Pemberian pupuk berlebih pada lahan pertanian dapat menambah atau mengurangi unsur mineral dalam tanah. Jika terjadi perubahan pada strukturnya, maka tanah tersebut diduga berpotensi mengalami kontaminasi yang berdampak pada kesuburan tanah. Pola tanam di suatu daerah pertanian Desa " $\mathrm{X}$ " menggunakan pupuk berlebih akibat masa tanam yang singkat sehingga perlu diindentifikasi tingkat kesuburan tanah pada lahan pertanian tersebut. Salah satu metode yang dapat digunakan adalah metode kelistrikan batuan. Metode ini menggunakan sifat kelistrikan magnet pada tanah yang dapat diamati untuk menentukan nilai konduktivitas tanah. Hasil penelitian menunjukkan lahan pertanian pada Desa "X" memiliki nilai konduktivitas yang beragam namun memiliki pola yang sama. Tetapi jika dibandingkan dengan tanah asli (bukan tanah pertanian), terdapat perbedaan yang mencolok. Selain menggunakan metode kelistrikan batuan, dilakukan pula pencocokan warna tanah menggunakan Munsell Color.
\end{abstract}

Kata-kata kunci: Kontaminasi, Konduktivitas, Kelistrikan Batuan, Munsell Color

\begin{abstract}
Excessive fertilizer on farmland can increase or decrease mineral elements in the soil. If there is a change in the structure, then the land is a suspected of having the potential to experience contamination that affects the soil fertility. Cropping pattern in a farm area village " $\mathrm{X}$ " uses excess fertilizer due to short planting period, so it needs to identify the level of soil fertility on the farmland. One method that could use is the electrical method of rock. This method uses the observable magnetic properties of the ground to figure the value of the soil conductivity. The results showed that farmland in Village " $\mathrm{X}$ " has diverse conductivity values but has the same pattern. But when compared with the original soil (not farmland), there are striking differences. In addition to using the electrical method of rock, also conducted the soil color matching using Munsell Color.
\end{abstract}

Keywords: Contamination, Conductivity, Rock Electrical, Munsell Color 


\section{PENDAHULUAN}

Kesuburan tanah merupakan mutu tanah yang menyediakan unsur hara tanaman dalam jumlah yang mencukupi kebutuhan tanaman dalam bentuk senyawa yang dapat dimanfaatkan tanaman melalui interaksi dengan memanfaatkan sifat fisika, kimia, dan biologi pada bagian tubuh tanah. Tanah yang subur memiliki kandungan unsur hara dan ketersediaan air yang cukup [1]. Jika pada mineral tanah terjadi perubahan struktur mineral dengan penambahan atau pengurangan unsur hara, maka tanah tersebut diduga berpotensi mengalami kontaminasi akibat penggunaan pupuk berlebih sehingga menurunkan tingkat kesuburan tanah [2].

Pemberian pupuk dilakukan dalam usaha menjaga kesuburan tanah yaitu untuk menjaga kandungan unsur hara dalam tanah yang telah hilang akibat kegiatan pertanian. Perbaikan sifat fisika tanah dapat dilakukan dengan menambahkan pupuk organik sedangkan perbaikan sifat kimia, dilakukan dengan penambahan pupuk anorganik. Namun jika penambahan pupuk dilakukan secara berlebihan akan berdampak pada kesuburan tanah sehingga mempengaruhi hasil panen. Tanah dapat dikatakan subur jika kaya akan unsur hara, memiliki kandungan organik yang cukup, kadar air dan $\mathrm{pH}$ yang sesuai [3].

Kabupaten Bandung Barat memiliki tanah Andosol yaitu tanah yang memiliki ciri warna hitam atau cokelat tua, struktur remah, licin jika dipirid, sangar berpori, kadar bahan organik tinggi, dan akumulasi liat sering ditemukan di lapisan bawah. Oleh sebab itu, daerah yang memiliki jenis tanah Andosol biasanya terdapat banyak lahan pertanian [4]. Suatu lahan pertanian di Desa " $X$ " yang berada di kawasan Kabupaten Bandung Barat memiliki pola tanam cepat panen sehingga cenderung memberikan banyak pupuk pada lahan pertaniannya, selain itu pola tanam tersebut sudah berlangsung selama 10 tahun sehingga dapat diindikasikan bahwa lahan tersebut memiliki banyak residu pupuk baik organik maupun anorganik. Penggunaan pupuk yang berlebihan dapat mengakibatkan kesuburan tanah menurun, maka perlu diindentifikasi tingkat kesuburan tanah pada lahan tersebut menggunakan metode kelistrikan batuan. Dengan demikian, hasil identifikasi ini diharapkan dapat bermanfaat, terutama bagi para petani sehingga dapat mengubah pola tanam atau frekuensi pemberian pupuk pada lahan pola tanam cepat panen.

\section{METODE PENELITIAN}

Bahan yang digunakan adalah tanah pertanian pada lahan cepat panen di Desa "X", Kabupaten Bandung Barat. Peralatan yang digunakan antara lain: pipa paralon, alat ukur Decagon EM-50 dengan sensor 5-TE, dan Munsell Color. Prosedur penelitiannya adalah sebagai berikut: pada tahap persiapan dilakukan pengumpulan informasi dan survei awal di lapangan untuk menentukan titik lokasi pengambilan conto. Pada tahap pelaksanaan, kegiatan yang dilakukan adalah pengambilan conto dengan teknik coring. Kedalaman maksimum coring adalah $70 \mathrm{~cm}$ karena merupakan kedalaman maksimum perakaran. Kemudian, pengukuran metoda kelistrikan batuan yang menghasilkan nilai konduktivitas listrik tanah menggunakan Decagon EM-50 dengan sensor 5-TE. Setelah itu, melakukan pencocokan warna tanah menggunakan Munsell Color untuk memberikan informasi tambahan mengenai warna tanah. Bagian akhir penelitian adalah analisis data konduktivitas listrik dan warna tanah untuk mengidentifikasi persebaran residu pupuk yang mempengaruhi tingkat kesuburan tanah pada lahan pertanian. Dengan demikian, hasil identifikasi ini diharapkan dapat menunjukan tingkat kesuburan tanah dan bermanfaat bagi para petani sehingga mengubah pola pemberian pupuk atau pola tanam pada lahan tersebut. 


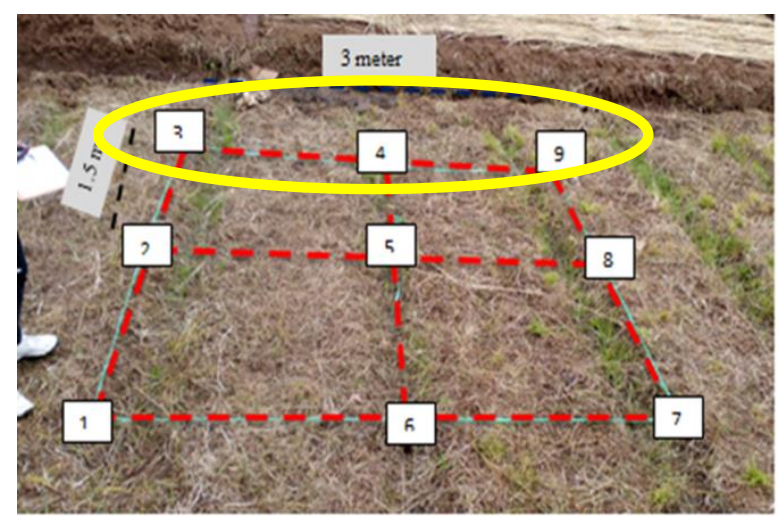

GAMBAR 1. Titik pengambilan coring, garis warna kuning menunjukan lintasan yang dibahas.

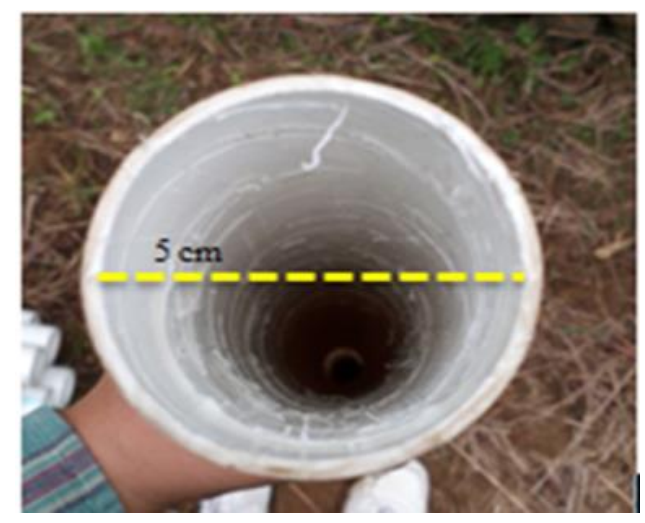

(a)



(b)

GAMBAR 2. (a)Pipa paralon yang digunakan untuk pengambilan conto. (b)Teknik coring.

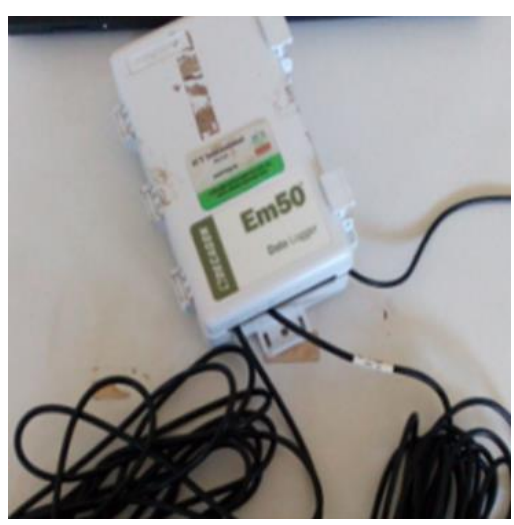

(a)

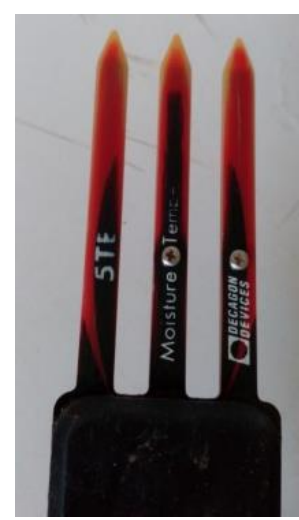

(b)

GAMBAR 3. (a) Decagon EM-50. (b) Sensor 5-TE untuk mengukur konduktivitas listrik tanah 




GAMBAR 4. Munsell Color untuk mencocokan warna tanah

\section{HASIL DAN PEMBAHASAN}

Berdasarkan data hasil pengukuran menunjukan bahwa K-3, K-4, dan K-9 memiliki rentang nilai konduktivitas listrik $0.3-0.7 \mathrm{dS} / \mathrm{m}$. Gambar 5a menunjukan bahwa nilai pada tiga titik pengambilan coring tersebut kedalaman tidak mempengaruhi nilai konduktivitas sedangkan jika di bandingkan pada gambar 6a terlihat pada tanah asli kedalaman memiliki pengaruh pada konduktivitas listrik. Pada tanah asli, semakin jauh kedalaman maka semakin tinggi nilai konduktivitas listrik. Menurut Golovko (2007), kandungan air atau fluida dalam tanah dapat mempengaruhi konduktivitas listrik pada tanah tersebut [5]. Pernyataan tersebut juga berlaku pada kondisi tanah K-3, K-4, dan K-9. Terdapat beberapa titik kedalaman yang memiliki nilai tinggi secara signifikan dibandingkan dengan kedalaman sebelumnya. Selain fluida, nilai konduktivitas listrik juga dipengaruhi oleh total kandungan bahan organik dan kandungan NPK [5]. Hal ini menunjukan bahwa terdapat indikasi residu pupuk yang terendapkan pada kedalaman tersebut. Oleh karena itu diperlukan pencocokan warna tanah untuk mengetahui endapan residu pupuk.

Warna tanah Andosol adalah gelap. Gambar 5b menunjukan diagram warna terukur pada titik K3, K-4, dan K-9. Titik K-3 berwarna cokelat tua keabuan dan cokelat tua. Kedua warna tersebut masih cenderung gelap sehingga diasumsikan tidak terdapat residu pupuk, sama halnya dengan titik K-4 yang berwarna cokelat tua keabuan. Pada K-9, dari permukaan hingga kedalaman $36 \mathrm{~cm}$ berwarna cokelat tua, kemudian berwarna hitam hingga kedalaman $48 \mathrm{~cm}$, dan selanjutnya berwarna kuning. Perubahan warna yang signfikan dari hitam menjadi kuning menunjukan bahwa pada kedalaman tersebut terdapat residu pupuk sehingga membuat tanah berwarna kekuningan. Selain itu, nilai konduktivitas sangat rendah yaitu $0.4 \mathrm{dS} / \mathrm{m}$.

Nilai konduktivitas listrik pada tanah juga menunjukan perubahan sub-lapisan atau sub-horizon. Hal ini dapat terlihat dari tanah yang memiliki kontras rendah diantara horizon atau sub-horizon [5]. Menurut Agustine, penentuan pola perlapisan tanah dilakukan dengan cara memiliki titik nilai konduktivitas listrik tanah yang tinggi, sebab konduktivitas listrik cenderung bernilai tinggi saat berada pada awal lapisan horizon maupun sub-horizon [6]. Gambar 7a menunjukan sub-lapisan dari titik K-3, K-4, dan K-9. Titik K-3 terindikasi memiliki dua lapisan sedangkan titik K-4 dan K-9 memiliki tiga lapisan. Namun jika diperhatikan terdapat nilai konduktivitas listrik yang memiliki pola berulang seperti pada titik K-3 $(5-30 \mathrm{~cm})$, K-4 $(25-40 \mathrm{~cm})$, dan K-9 $(5-25 \mathrm{~cm})$. Jika dibandingkan pada tanah asli (Gambar 7b) tidak terdapat pola berulang. Perulangan tersebut disebabkan oleh proses mekanisasi saat kegiatan pertanian berlangsung yang mempengaruhi nilai konduktivitas listrik tanah terukur. 






(a)
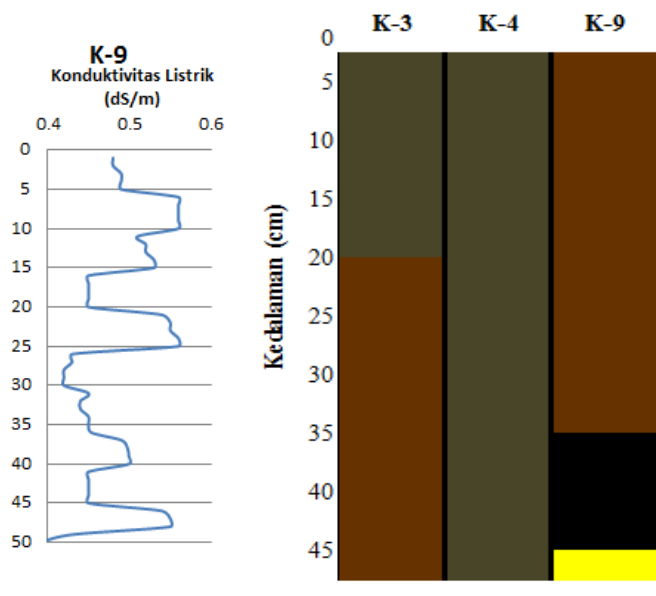

(b)

GAMBAR 5. (a)Nilai konduktivitas listrik titik K-3, K-4, dan K-9 (garis biru menunjukan nilai konduktivitas listrik terukur). (b) Warna tanah hasil pencocokan menggunakan Munsell Color.

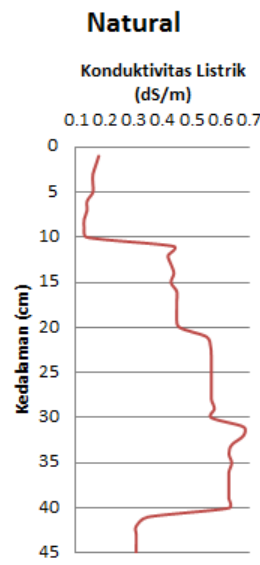

(a)

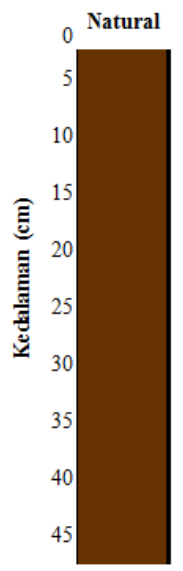

(b)

GAMBAR 6. (a)Nilai konduktivitas listrik pada tanah asli atau natual (garis merah menunjukan nilai konduktivitas listrik terukur). (b) Warna tanah hasil pencocokan menggunakan Munsell Color.

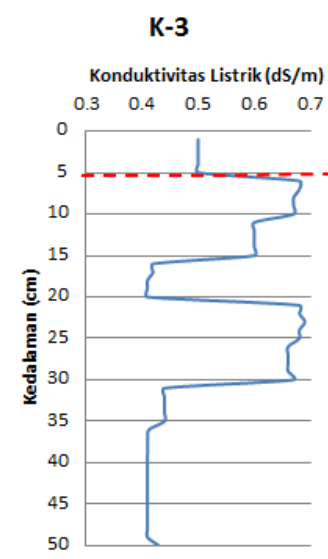

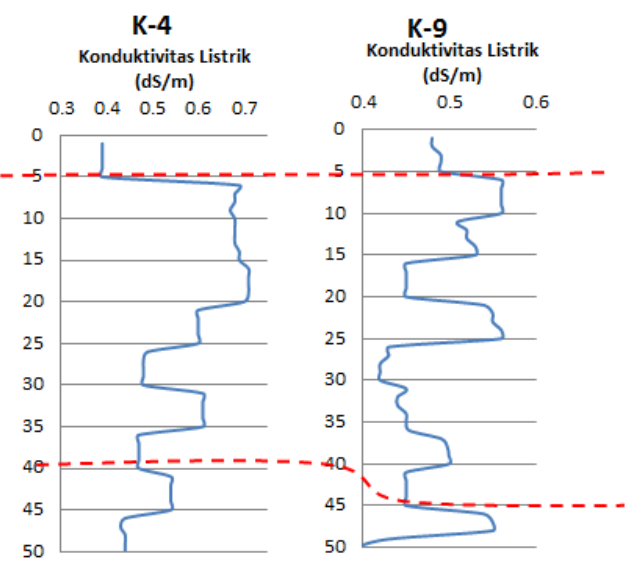

(a)

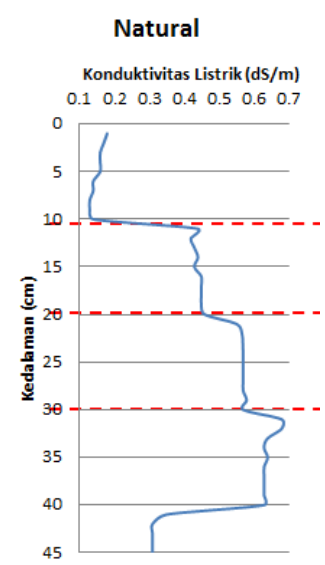

(b)

GAMBAR 7. (a) Penentuan sub-lapisan pada titik K-3, K-4, dan K-9 (garis biru menunjukan nilai konduktivitas listrik terukur dan garis merah putus-putus menunjukan pembagian sub-lapisan). (b) Penentuan sub-lapisan pada tanah asli atau natural (garis biru menunjukan nilai konduktivitas listrik terukur dan garis merah putus-putus menunjukan pembagian sublapisan). 


\section{KESIMPULAN}

Nilai konduktivitas tanah dari pengukuran metoda kelistrikan batuan dapat menunjukan jumlah sub-lapisan dan proses mekanisasi yang terjadi pada lahan tersebut. Selain itu, nilai konduktivitas listrik yang sangat rendah mengindikasikan terdapat residu pupuk pada kedalaman tersebut yang terlihat dari perubahan warna menggunakan Munsell Color. Namun untuk memperkuat simpulan tersebut, perlu dilakukan penelitian pada bidang pertanian untuk memastikan tingkat kesuburan tanah pada lahan tersebut.

\section{UCAPAN TERIMAKASIH}

Kami ucapkan terima kasih kepada rekan-rekan Geofisika Universitas Padjadjaran 2012 atas bantuannya selama di lapangan dan Silvia beserta rekan-rekan laboratorium kemagnetan batuan FTTM-ITB selama pengerjaan di laboratorium.

\section{REFERENSI}

[1] J. Yunda, "Studi Awal Penggunaan Metode Kemagnetan Batuan dan Parameter Fisika Untuk Analisis Kesuburan Tanah," unpublished.

[2] Mulyadi, "Logam Berat Pb Pada Tanah Sawah dan Gabah di Sub-DAS Juwana Jawa Tengah," Agrologia, vol. 2, no. 2, pp. 95-101, Oct. 2013.

[3] L.A. Rakhmawati, "Analisis Parameter Fisika Tanah dan Sebaran Kotaminasi untuk Lahan Terpapar Residu Pupuk," unpublished.

[4] Sukarman and A. Dariah, Tanah Andosol di Indonesia Karakteristik, Potensi, Kendala, dan Pengelolaannya untuk Pertanian. Bogor, Indonesia: Balai Besar Penelitian dan Pengembangan Sumberdaya Lahan Pertanian, 2014, pp. 3-4.

[5] L. Golovko and A.I. Pozdnyakov, "Electrical Geophysical Methods in Agriculture," Proceedings of the 4th International Symposium on Intelligent Information Technology in Agriculture, pp. 457-471, Oct. 2007.

[6] E. Agustine, "Kajian Suseptibilitas Magnetik dan Konduktivitas Listrik Pada Tanah Vulkanik yang Terpapar Pestisida Organochlorine," Ph.D. dissertation, Teknik Geofisika, ITB., Bandung, Indonesia, 2015. 